\title{
Retraction
}

\section{Retracted: New 1,2,3-Triazole Iminosugars Derivatives Using Click Chemistry}

\section{International Journal of Carbohydrate Chemistry}

Received 22 December 2014; Accepted 22 December 2014; Published 31 December 2014

Copyright ( 2014 International Journal of Carbohydrate Chemistry. This is an open access article distributed under the Creative Commons Attribution License, which permits unrestricted use, distribution, and reproduction in any medium, provided the original work is properly cited.

This article has been retracted as it was submitted for publication without the prior knowledge or approval of Dr. Aloysius Siriwardena, who has contributed to the article. Additionally, it has been submitted without prior approval of the Centre National de la Recherche Scientifique (CNRS) and the laboratory in which the intellectual ideas behind the syntheses were established [1].

\section{References}

[1] C. Benhaoua, "New 1,2,3-triazole iminosugars derivatives using click chemistry," International Journal of Carbohydrate Chemistry, vol. 2012, Article ID 394574, 10 pages, 2012. 


\title{
New 1,2,3-Triazole Iminosugars Derivatives Using Click Chemistry
}

\author{
Chahrazed Benhaoua
}

Laboratoire Synthèse et Catalyse, LSCT, Université Ibn Khaldoun, Tiaret 14000, Algeria

Correspondence should be addressed to Chahrazed Benhaoua, ch_benhaoua@mail.univ-tiaret.dz

Received 17 March 2012; Accepted 28 April 2012

Academic Editor: R. J. Linhardt

Copyright $\odot 2012$ Chahrazed Benhaoua. This is an open access article distributed under the Creative Commons Attribution License, which permits unrestricted use, distribution, and reproduction in any medium, provided the original work is properly cited.

The click concept refers ease, efficient, and the selective chemicals transformations. In this study, a novel regiospecific copper (I)catalyzed 1,3-dipolar of terminal alkynes to azide provided a practicable synthetic pathway of triazole iminosugars derivatives. A series of new triazole-pyrrolidinols are reported in good yield.

\section{Introduction}

There are considerable interests in the design of molecules that are able to mimic carbohydrates which play critical roles in various biological events. This is shown by the following example, the 1-deoxynojirimycin (DNJ) family, for which DNJ itself is a competitive inhibitor of $\alpha$-D-glucosidase $(K i=8--25 \mu \mathrm{M})[1]$, while its derivatives Miglustat $(N$ $n$ Bu DNJ, Zavesa) and Miglitol ( $N$-hydroxyethyl DNJ, Glyset, or Diastabol) have already found therapeutic applications in Gaucher's disease [2] and type 2 (noninsulin-dependant mellitus) diabetes, respectively [3, 4] (Figure 1). Recently, researches have increasingly accorded to new iminosugars from click chemistry [5].

The term click chemistry was introduced by Sharpless and coworkers and promotes the use of efficient, selective, and versatile chemical reactions in synthetic chemistry [6].

The basic reaction, which is nowadays summed up under the name "Sharpless-type click reaction," is a variant of the Huisgen 1,3-dipolar cycloaddition reaction between CC triple bonds and alkyl azides $[7,8]$ (Scheme 1).

Meldal and coworkers published a paper in 2002 that describes the acceleration of this process by CuI salts that leads to a reaction at $25^{\circ} \mathrm{C}$ in quantitative yields. It was mentioned that the organic azides and the terminal alkynes are united to afford 1,4-regioisomers of 1,2,3-trialoes as sole products [9].
The source of $\mathrm{Cu}(\mathrm{I})$ salts commonly used involves the reduction of copper(II) sulfate by sodium ascorbate [9], although other conditions have been described, such as $\mathrm{Cu}(\mathrm{I})$ [10] salts, $\mathrm{Cu}(\mathrm{I})$ complexes [11] and stabilized derivatives of $\mathrm{Cu}(\mathrm{I})$ [9]. The bases used are mostly triethylamine, 2,6lutidine and $\mathrm{N}, \mathrm{N}$-diisopropylethylamine (DIPEA).

1.1. Click Chemistry and Synthesis of Iminosugars Derivatives. The application of CuAAC-catalysed reactions for the synthesis of new $\alpha$-glucosidase inhibitors containing a 1-deoxynojirimycin (DNJ) was described by Murphy and coworkers.

These compounds indicate that it is possible to modulate the potency and the selectivity towards different glycosidases [5] (Figure 2).

More recently, Diot et al. reported the synthesis of several iminosugars from a click chemistry reaction between oligoethylene scaffolds and $\mathrm{N}$-substituted $\mathrm{DNJ}$ derivative.

Thus, compounds of $\mathbf{4}(n=1)$ and $\mathbf{5}(n=4)$ derivatives of the DNJ-based are good inhibitors of different glycosidases [12] (Figure 3).

Kumar et al. reported the synthesis of various pyrrolidine-triazoles, these compounds are achieved by using this intramolecular cycloaddition reaction in water with complete 1,5 regioselectivity [13] (Figure 4).

Researches for new five-membered iminosugars as potential inhibitors of glycosidases reported the synthesis of 


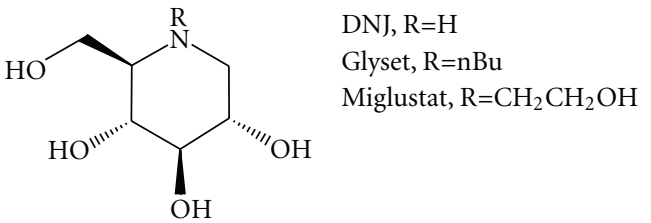

FIGURE 1: Structure of inhibitors of glycosidases.

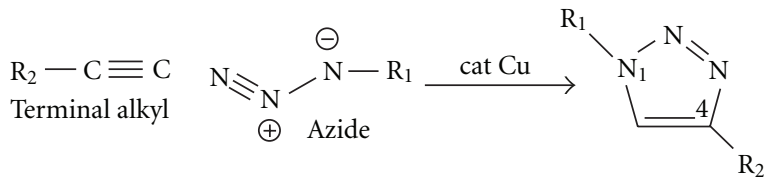

Scheme 1: 1,3-dipolar cycloaddition reaction.

1,2,3-triazole iminosugars from a click chemistry reaction between polyhydroxylated pyrrolidine and different azide.

\section{Results and Discussion}

2.1. Synthesis of 1,2,3-Triazoles Iminosugars. As illustrated in Scheme 2, a protected triazole-pyrrolidine (9) was obtained by condensation of an appropriate azide and the protected pyrrolidine $(\mathbf{8})$.

From the data presented in Table 1, it was noticed that the compounds (9) are prepared in yields ranging from $60 \%$ to $84 \%$.

2.2. Identification of Products. The structure elucidation of compounds 9 (a-e) achieved on the basis of their ${ }^{1} \mathrm{H}$ NMR, ${ }^{13} \mathrm{C}$ NMR and masse spectra.

The ${ }^{1} \mathrm{H}$ and ${ }^{13} \mathrm{C}$ NMR spectra showed the formation of the 1,2,3-triazole ring.

For the products 7 (a-e), the signal for the $\mathrm{H}_{5}$ proton of the pyrrolidine cycle is around $4.11 \mathrm{ppm}$ to $4.71 \mathrm{ppm}$.

In the ${ }^{13} \mathrm{C}$ NMR of the compounds 9 (a-e), characteristic $(\mathrm{C}=\mathrm{O})$ appeared at around 169.78 to 173.82 . The ${ }^{13} \mathrm{C} N M R$ spectrum of all the compounds showed the characteristic of signal for the $\left(\mathrm{C}(\mathrm{Me})_{2}\right)$ of isopropylidene at around 112.47 to $115.44 \mathrm{ppm}$.

The characteristic $(\underline{\mathrm{C}}-\mathrm{N}=\mathrm{N}-\mathrm{N})$ appeared at around 135.23 to $148.96 \mathrm{ppm}$ and the characteristic $(\underline{\mathrm{C}}-\mathrm{N}-\mathrm{N}=\mathrm{N})$ is recorded at around $122.98-124.75 \mathrm{ppm}$.

The yield of compounds (9d) and (9e) is 60\%. These results are confirmed to the values of Haridas and coworkers in the synthesis of series of triazoalphanes [14].

\section{Conclusion}

A series of novel 1,2,3-triazoles iminosugars are synthesized from protected polyhydroxylated pyrrolidine $(\mathbf{8})$. In this work, we have shown that the copper-catalyzed Huisgen cycloaddition of terminal alkyne is a general process affording the 1,4-disubstituted triazole isomer in good yields. This

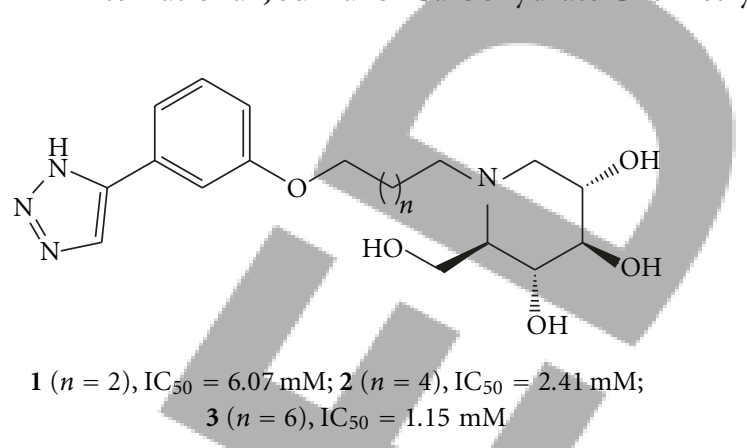

FIGURE 2: Structures of triazole iminosugars as potential glycosidase inhibitors.

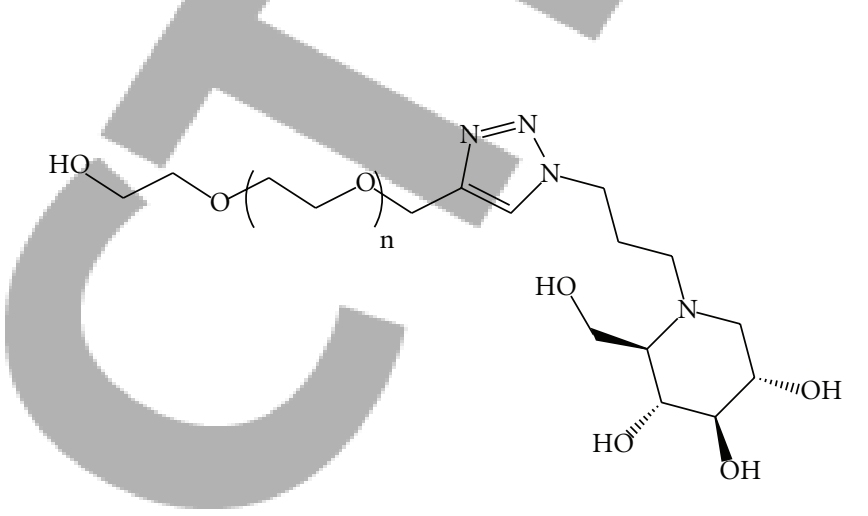

FIGURE 3: New triazole -DNJ derivatives.
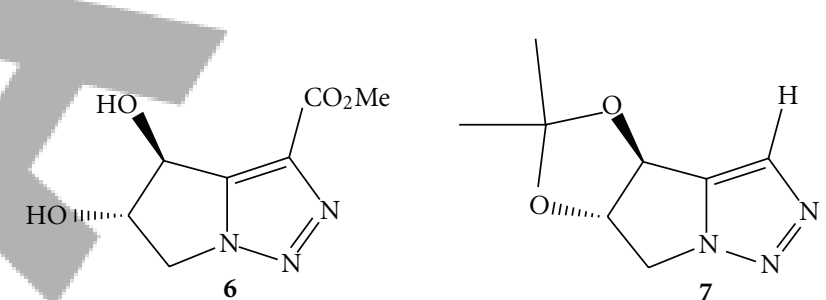

FIGURE 4: Various pyrrolidine-triazole.

reaction proceeds under mild conditions to afford only one regioisomer.

Work is underway to apply parallel synthesis of triazolepyrrolidine by condensation of the protected azido-pyrrolidine and an appropriate alkyne. After the deprotection, we study the biological activities of all triazoles-iminosugars.

\section{Experimental}

4.1. Materials and Equipments. Chemicals were purchased from Aldrich, Acros, and Fluka and used without further purification. Solvents distilled with appropriate drying agents. All reactions performed under anhydrous conditions employing routine drying techniques unless otherwise indicated. Reactions were monitored by thin-layer chromatography (TLC) performed on E. Merck glass plates silica gel sheets (Silica $\mathrm{Gel} \mathrm{F}_{254}$ ) and stained with vanillin acidaqueous $\mathrm{H}_{2} \mathrm{SO}_{4}$ solution. Column chromatography carried out on silica gel (E. Merck 230-400 mesh). Nuclear magnetic Resonance $(\mathrm{NMR})$ data $\left({ }^{1} \mathrm{H}\right.$ or $\left.{ }^{13} \mathrm{C}\right)$ were obtained on a 


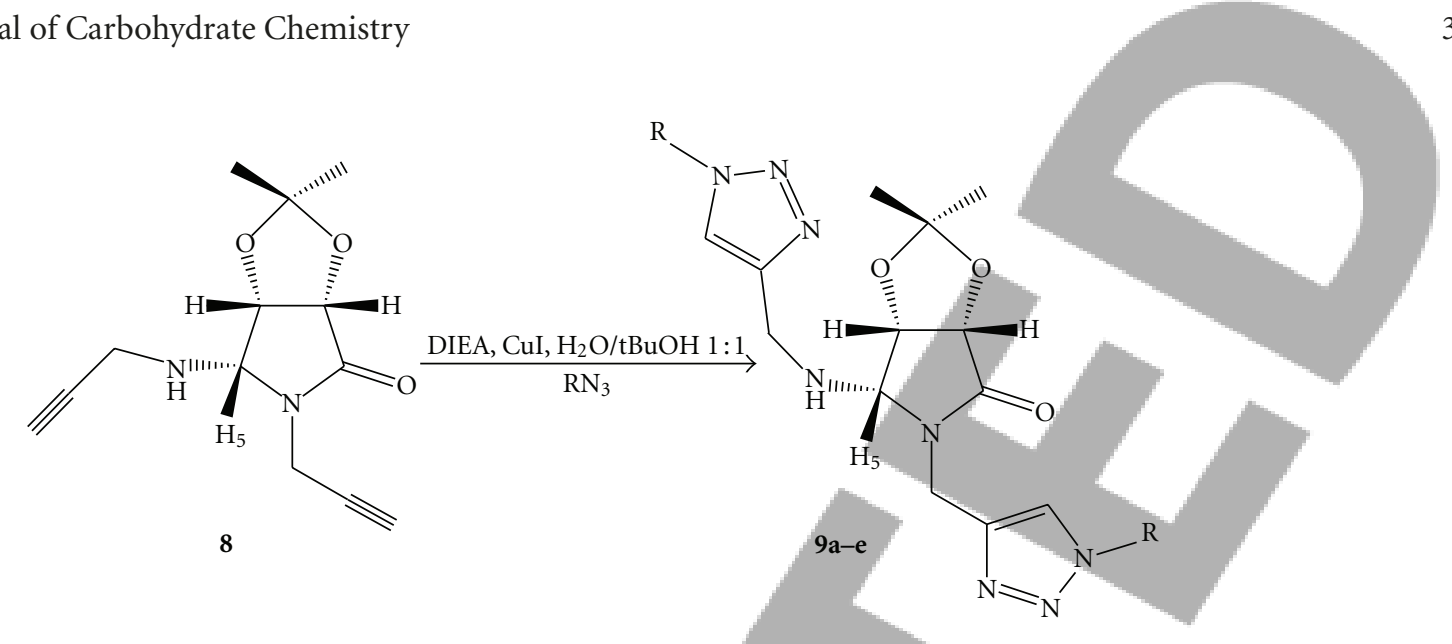

Scheme 2: Synthesis of 1,2,3-triazole iminosugars.

AC-Brucker 300 machine chemical shifts are reported in parts per million relative to tetramethylsilane in deuterated solvents. Assignments of ${ }^{1} \mathrm{H}$ and ${ }^{13} \mathrm{C}$ were assisted by $2 \mathrm{D}$ ${ }^{1} \mathrm{H}$ COSY and 2D ${ }^{1} \mathrm{H}-{ }^{13} \mathrm{C}$ CORR experiments. Optical rotations were determined with a Jasco Dip 370 electronic micropolarimeter $(10 \mathrm{~cm}$ cell). Low resolution electrospray mass spectra (ESIMS) in the positive ion mode were obtained on a Waters-Micromass ZQ quadrupole instrument, equipped with an electrospray (Z-spray) ion source (WatersMicromass, Manchester, UK). High-resolution electro spray mass spectra (ESI-HRMS) in the positive ion mode were obtained on a Q-TOF Ultima Global hybrid quadrupole time-of-flight instrument (Waters-Micromass), equipped with a pneumatically assisted electro spray (Z-sprayl) ionization source and an additional sprayer (Lock Spray) for the reference compound. The compound $(\mathbf{8})$ is synthesized as described in the literature [15].

4.2. General Procedure for Synthesis of Azide: $R N_{3}$. The alkyl or benzyl chloride (1.0 equiv) was suspended in water at concentration of $1.5 \mathrm{M}$. Sodium azide (3.0 equiv) and ammonium chloride (2.0 equiv) were added, and the reaction was heated at $80^{\circ} \mathrm{C}$ for $48 \mathrm{~h}$ with vigorous stirring. The aqueous layer was extracted with diethyl ether, dried with $\mathrm{MgSO}_{4}$ and solvent was evaporated to yield pure azide [16].

Benzyl azide: 97\%, 3-azido-propane-1-ol: 92\%: 3-azidopropionitrile: $82 \%, 1,4$ bis (azidomethyl) benzene: $45 \%, 1,3$ bis (azidomethyl) benzene: $45 \%$.

4.3. General Procedure for Synthesis of 1,2,3-triazoles-Iminosugars (9). A mixture of alkyne $11(0.43 \mathrm{mmol})$ and the appropriate azide $(1.73 \mathrm{mmol})$ were dissolved in a solution of water and $\mathrm{t}-\mathrm{BuOH}(1: 1)$. To this solution was added DIEA (diisopropyl ethylamine) $(0.26 \mathrm{mmol})$ and $\mathrm{CuI}(0.17 \mathrm{mmol})$. The reaction was stirred at room temperature overnight. After, the water $(20 \mathrm{~mL})$ was added to dilute the solution and the mixture was then extracted with $\mathrm{CH}_{2} \mathrm{Cl}_{2}(3 \times 20 \mathrm{~mL})$. The organic layer was dried over $\mathrm{Na}_{2} \mathrm{SO}_{4}$, concentrated and purified by column $\left(\mathrm{CH}_{2} \mathrm{Cl}_{2} / \mathrm{MeOH}, 95 / 5\right)$. The characterization of each compound obtained by means of NMR and mass spectrometry as reported below.
4.3.1. N-(1-(3-hydroxypropyl)1H-1,2,3-triazol-4-methyl)-3.4O-isopropylidendioxy-5-(3-hydroxypropyl)1H-1,2,3-triazol4-yl)methylamino)pyrrolidin-2-one (9a). Colorless syrup. $[\alpha]_{D}^{20}=+1.33(\mathrm{C}=0.53, \mathrm{MeOH}), \mathrm{NMR}{ }^{1} \mathbf{H}(300 \mathrm{MHz}$, $\left.\mathrm{CDCl}_{3}\right): \delta 1.41(\mathrm{~s}, 3 \mathrm{H}) ; 1.44(\mathrm{~s}, 3 \mathrm{H}) ; 2.08-2.17(\mathrm{~m}, 4 \mathrm{H})$; $3.58-3.64(\mathrm{~m}, 4 \mathrm{H}) ; 4.02-4.07$ (d, $1 \mathrm{H}, \mathrm{J}=14.47 \mathrm{~Hz}) ; 4.13-$ $4.18(\mathrm{~d}, 1 \mathrm{H}, \mathrm{J}=14.47 \mathrm{~Hz}) ; 4.45-4.60(\mathrm{~m}, 7 \mathrm{H}), 4.69-4.74$ $(\mathrm{d}, 1 \mathrm{H}, J=14.90 \mathrm{~Hz}) ; 4.76-4.78(\mathrm{~m}, 1 \mathrm{H}, J=5.19 \mathrm{~Hz})$; $7.66(\mathrm{~s}, 1 \mathrm{H}, \mathrm{CH}-\mathrm{N}-\mathrm{N}=\mathrm{N}) ; 7.89(\mathrm{~s}, 1 \mathrm{H}, \underline{\mathrm{CH}}-\mathrm{N}-\mathrm{N}=\mathrm{N})$. NMR ${ }^{13} \mathrm{C}\left(75 \overline{\mathrm{MHz}}, \mathrm{CDCl}_{3}\right): \delta 25.95 ; 27.05 ; 32.44 ; 34.54$; $41.54 ; 47.04 ; 58.38-58.53 ; 71.06 ; 73.01 ; 77.28 ; 112.97 ; 123.15$ $(\underline{\mathrm{C}}-\mathrm{N}-\mathrm{N}=\mathrm{N}) ; 123.71(\underline{\mathrm{C}}-\mathrm{N}-\mathrm{N}=\mathrm{N}) ; 143.16(\underline{\mathrm{C}}-\mathrm{N}=\mathrm{N}-\mathrm{N})$; $146.49(\underline{\mathrm{C}}-\mathrm{N}=\mathrm{N}-\mathrm{N}) ; 169.92(\mathrm{C}=\mathrm{O})$. HRMS (m/z) $[\mathrm{M}+\mathrm{Na}]^{+}$ calcd for $\mathrm{C}_{19} \mathrm{H}_{30} \mathrm{~N}_{8} \mathrm{O}_{5} \mathrm{Na}=473.2237$, found: 473.2226 .

4.3.2. N-1-(2-cyanoeth) $1 \mathrm{H}-1,2,3$ - triazol-4-methyl)-3.4-Oisopropylidendioxy-5-(2-cyanoethyl)-1H-1,2,3-triazol-4-yl)) methylamino)pyrrolidin-2-one (9b). Yellow gum, $[\alpha]_{D}^{20}=$ $+0.83(\mathrm{C}=0.22, \mathrm{MeOH}), \mathbf{N M R}{ }^{1} \mathbf{H}\left(300 \mathrm{MHz}, \mathrm{CDCl}_{3}\right)$ : $\delta 1.36(\mathrm{~s}, 3 \mathrm{H}) ; 1.1 .40(\mathrm{~s}, 3 \mathrm{H}) ; 3.1-3.01(\mathrm{~m}, 4 \mathrm{H}) ; 3.9-4.03$ $(\mathrm{d}, 1 \mathrm{H}, J=14.25 \mathrm{~Hz}) ; 4.1-4.15(\mathrm{~d}, 1 \mathrm{H}, J=14.46 \mathrm{~Hz})$; 4.29-4.72 (m, 9H), 7.79 (s, 1H, CH-N-N=N); $7.91(\mathrm{~s}, 1 \mathrm{H}$, $\underline{\mathrm{CH}}-\mathrm{N}-\mathrm{N}=\mathrm{N})$; NMR ${ }^{13} \mathrm{C}\left(75 \mathrm{MHz}, \mathrm{CDCl}_{3}\right): \delta 19.25 ;-19.33$; 25.91; 257.01; 34.46; 41.54; 45.50-45.56; 71.28; 73.16; 77.30; $112.90 ; 116.91-117.00 ; 123.09$ ( $\underline{\mathrm{C}}-\mathrm{N}-\mathrm{N}=\mathrm{N}) ; 123.77$ ( $\underline{\mathrm{C}}-\mathrm{N}-$ $\mathrm{N}=\mathrm{N}) ; 143.56(\underline{\mathrm{C}}-\mathrm{N}=\mathrm{N}-\mathrm{N}) ; 147.18(\underline{\mathrm{C}}-\mathrm{N}=\mathrm{N}-\mathrm{N}) ; 169.78$ $(\mathrm{C}=\mathrm{O})$. HRMS $(\mathbf{m} / \mathbf{z})[\mathrm{M}+\mathrm{Na}]^{+}$calcd for $\mathrm{C}_{19} \mathrm{H}_{24} \mathrm{~N}_{10} \mathrm{O}_{3} \mathrm{Na}$ : 463.1931, found: 463.1920 .

4.3.3. N1-(1-benzyl-1H-1,2,3-triazol-4-yl)methyl-3,4-O-isopropylidendioxy-5-(1-benzyl-1H-1,2,3-triazol-4-yl)methylamino)pyrrolidin-2-one (9c). Yellow solid, $\mathrm{Mp}=149-150^{\circ} \mathrm{C}$. $[\alpha]_{D}^{20}+1.16(\mathrm{C}=0.22, \mathrm{MeOH}) . \quad \mathrm{NMR}{ }^{1} \mathbf{H}(300 \mathrm{MHz}$, $\left.\mathrm{CDCl}_{3}\right): \delta 1.33(\mathrm{~s}, 6 \mathrm{H}) ; 3.92-3.97(\mathrm{~d}, \mathrm{H}, J=14.32 \mathrm{~Hz})$; 3.92-3.97 (d, H, J = 14.42 Hz); 4.49 (m, 2H), 4.58 (d, $1 \mathrm{H}$, $J=5.6 \mathrm{~Hz}) ; 4.65(\mathrm{~m}, 1 \mathrm{H}, J=5.01 \mathrm{~Hz}) ; 4.72(\mathrm{~m}, 1 \mathrm{H})$; 5.79-5.52 (m, 4H); 7.24-7.26 (m, H-aromatic); 7.55-7.56 (2s, 2H, CH-N). NMR ${ }^{13} \mathrm{C}\left(75 \mathbf{M H z}, \mathbf{C D C l}_{3}\right): \delta 25.64 ; 26.71$; $34.61 ; 41.51 ; 71.82 ; 73.41 ; 77.38 ; 112.72 ; 123.53$ (ㄷ-N$\mathrm{N}=\mathrm{N}) ; 124.35$ ( $\underline{\mathrm{C}}-\mathrm{N}-\mathrm{N}=\mathrm{N}) ; 128.3-129.00$ (C-aromatic); 134.77-134.96 (C-aromatic); 143.28 (C-N=N-N); 147.11 
TABLE 1: Result for the preparation of protected 1,2,3-triazole iminosugars (9).

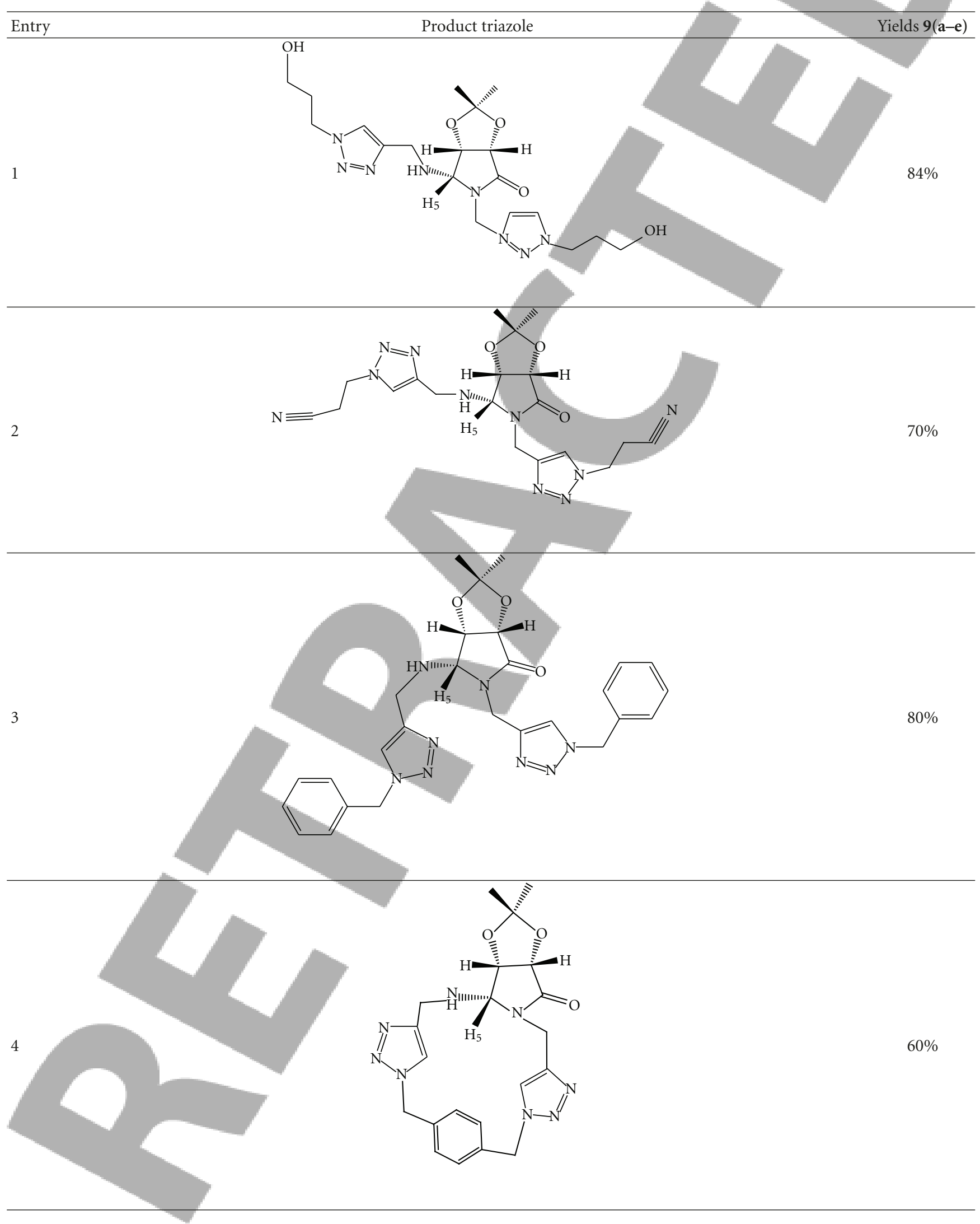


$(\mathrm{C}-\mathrm{N}=\mathrm{N}-\mathrm{N}) ; 170.43(\mathrm{C}=\mathrm{O})$. HRMS $(\mathrm{m} / \mathbf{z})[\mathrm{M}+\mathrm{Na}]^{+} \mathrm{calcd}$ for $\mathrm{C}_{27} \mathrm{H}_{30} \mathrm{~N}_{8} \mathrm{O}_{3} \mathrm{Na}$ : 537.2336, found: 537.2316.

4.3.4. N1-(4-((1H-1,2,3-triazol-1-yl)methyl)benzyl)-3,4-Oisopropylidendioxy-5-(1H-1,2,3-triazol-4-yl)methylamino) pyrrolidin-2-one (9d). Yellow gum, $[\alpha]_{D}^{20}+1.5(\mathrm{C}=0.19$, $\mathrm{MeOH})$. NMR ${ }^{1} \mathbf{H}\left(300 \mathbf{M H z}, \mathbf{C D C l}_{3}\right): \delta 1.38-1.40$ (s, $6 \mathrm{H})$; 4.09-4.09 (d, $1 \mathrm{H}, J=14.68 \mathrm{~Hz}) ; 4.15-4.20(\mathrm{~d}$, $1 \mathrm{H}, J=14.68 \mathrm{~Hz}) ; 4.38(\mathrm{~m}, 2 \mathrm{H}), 4.54-4.56(\mathrm{~m}, 3 \mathrm{H}$, $J=5.92 \mathrm{~Hz}) ; 4.70(\mathrm{~m}, 2 \mathrm{H}) ; 5.47-5.56(\mathrm{~m}, 2 \mathrm{H}) ; 7.30-7.37$ (m, H-aromatic); 7.51 (s, 1H, CH-N); $7.72(\mathrm{~s}, 1 \mathrm{H}, \mathrm{CH}-\mathrm{N})$. NMR ${ }^{13} \mathrm{C}\left(75 \mathrm{MHz}, \mathrm{CDCl}_{3}\right): \delta 24.97 ; 26.09 ; 34.34 ; 41.08$; $53.24-53.74 ; 71.90 ; 73.53 ; 77.45 ; 112.47 ; 122.98$ ( $\underline{C}-\mathrm{N}-$ $\mathrm{N}=\mathrm{N}) ; 123.49(\underline{\mathrm{C}}-\mathrm{N}-\mathrm{N}=\mathrm{N}) ; 128.21-128.62$ (C-aromatic); $135.23(\underline{\mathrm{C}}-\mathrm{N}=\mathrm{N}-\mathrm{N}) ; 136.24(\underline{\mathrm{C}}-\mathrm{N}=\mathrm{N}-\mathrm{N}) ; 170.84(\mathrm{C}=\mathrm{O})$. HRMS $(\mathbf{m} / \mathbf{z})[\mathbf{M}+\mathrm{Na}]^{+}$calcd for $\mathrm{C}_{27} \mathrm{H}_{30} \mathrm{~N}_{8} \mathrm{O}_{3} \mathrm{Na}$ 437.2050, found 437.2064.

4.3.5. N1-(3-((1H-1,2,3-triazol-1-yl)methyl)benzyl)3,4-Oisopropylidendioxy-5-(1H-1,2,3-triazol-4-yl)methylamino) pyrrolidin-2-one $(9 e)$. Marrow syrup, $[\alpha]_{D}^{20}=3.0(\mathrm{C}=0.22$, $\mathrm{MeOH}) . \mathbf{N M R}{ }^{1} \mathbf{H}\left(\mathbf{3 0 0} \mathbf{M H z}, \mathbf{C D C l}_{3}\right): \delta 1.45(\mathrm{~s}, 3 \mathrm{H}) ; 1.53$ $(\mathrm{s}, 3 \mathrm{H}) ; 1.62-1.71(\mathrm{NH}) ; 4.11-4.13(\mathrm{~m}, 3 \mathrm{H}) ; 4.44-4.49(\mathrm{~d}$, $1 \mathrm{H}, J=15.35 \mathrm{~Hz}) ; 4.67-4.69(\mathrm{~d}, 1 \mathrm{H}, J=5.92 \mathrm{~Hz}) ; 4.80-4.84$ $(\mathrm{m}, 1 \mathrm{H}, J=5.92 \mathrm{~Hz}) ; 5.09-5.14(\mathrm{~d}, 1 \mathrm{H}, J=15.13 \mathrm{~Hz})$; 5.47-5.69 (m, 2H); 7.36-7.42 (m, H-aromatic); 7.52 (s, 1H, $\mathrm{CH}-\mathrm{N}) ; 7.60$ (s, 1H, CH-N); 7.78-7.83 (m, H-aromatic). NMR 13C (75 MHz, $\left.\mathrm{CDCl}_{3}\right): \delta 27.87 ; 29.00 ; 36.53-42.27$; $56.65-56.96 ; 71.52 ; 74.97 ; 80.03 ; 115.44 ; 124.54$ ( $\underline{\mathrm{C}}-\mathrm{N}-$ $\mathrm{N}=\mathrm{N}) ; 124.75(\mathrm{C}-\mathrm{N}-\mathrm{N}=\mathrm{N}) ; 126.43$ (C-aromatic); 141.10 (C-aromatic); $143.96(\underline{\mathrm{C}}-\mathrm{N}=\mathrm{N}-\mathrm{N}) ; 148.96(\underline{\mathrm{C}}-\mathrm{N}=\mathrm{N}-\mathrm{N})$; 156.64 (C-aromatic); $173.82(\mathrm{C}=\mathrm{O})$. HRMS (m/z) $[\mathbf{M}+\mathbf{N a}]^{+}$ calc for $\mathrm{C}_{20} \mathrm{H}_{23} \mathrm{~N}_{9} \mathrm{O}_{3} \mathrm{Na}$ : 460.1822 , found: 460.1814 .

4.3.6. N-1-(2-propynyl)-3,4-O-isopropylidendioxy-5-(2-propynylamino)pyrrolidin-2-one (8). This compound was obtained as a method described in the literature [14]. Colorless syrup. $[\alpha]_{D}^{20}=-2.43(\mathrm{C}=0.55, \mathrm{MeOH}) ; \mathrm{NMR}^{1} \mathbf{H}$ $\left(\mathrm{CDCl}_{3}\right): \delta 4.91(\mathrm{~m}, 1 \mathrm{H}, \mathrm{H}-4, J=4.49 \mathrm{~Hz}) .4 .75(\mathrm{~m}, 2 \mathrm{H}$, $\mathrm{H}-5, \mathrm{H}-3, J=6.08 \mathrm{~Hz}) ; 4.42(\mathrm{dd}, 1 \mathrm{H},-\mathrm{CH} 2-, J=14.63$,
$2.51 \mathrm{~Hz}) ; 3.89(\mathrm{dd}, 1 \mathrm{H},-\mathrm{CH} 2-, J=14.64,2.5 \mathrm{~Hz}) ; 3.33(\mathrm{~m}$, 2H, -CH2-); 2.24-2.26 (m, 2H, -CH-); 1.37 (s, 6H, $\mathrm{CH}_{3}$ ). NMR ${ }^{13} \mathbf{C}\left(\mathrm{CDCl}_{3}\right) \delta 168.76(\mathrm{C}=\mathrm{O}) ; 112.92 ; 82.12 ; 77.64$; $73.39 ; 72.01 ; 71.21-71.78 ; 36.15 ; 28.79 ; 26.06-26.97$. HRMS $(\mathrm{m} / \mathbf{z})[\mathrm{M}+\mathrm{Na}]^{+}$calcld for $\mathrm{C}_{13} \mathrm{H}_{16} \mathrm{~N}_{2} \mathrm{O}_{3} \mathrm{Na} 271.1059$, found: 271.1065 .

\section{Acknowledgments}

C. Benhaoua thanks the Scientific Ministry for Higher Education and Research of Algeria for fellowships and thanks Dr D. Turki for helping in the English correction of the paper.

\section{References}

[1] A. Mitrakou, N. Tountas, A. E. Raptis, R. J. Bauer, H. Schulz, and S. A. Raptis, "Long-term effectiveness of a new alphaglucosidase inhibitor (BAY m1099-miglitol) in insulin-treated type 2 diabetes mellitus," Diabetic Medicine, vol. 15, no. 8, pp. 657-660, 1998.

[2] L. J. Scott and C. M. Spencer, "Miglitol: a review of its therapeutic potential in type 2 diabetes mellitus," Drugs, vol. 59, no. 3, pp. 521-549, 2000.

[3] T. M. Block, X. Lu, F. M. Platt et al., "Secretion of human hepatitis B virus is inhibited by the imino sugar N-butyldeoxynojirimycin," Proceedings of the National Academy of Sciences of the United States of America, vol. 91, no. 6, pp. 2235-2239, 1994.

[4] A. Mehta, S. Carrouee, B. Conyers et al., "Inhibition of hepatitis B virus DNA replication by imino sugars without the inhibition of the DNA polymerase: therapeutic implications," Hepatology, vol. 33, no. 6, pp. 1488-1495, 2001.

[5] B. Andersen, A. Rassov, N. Westergaard, and K. Lundgren, "Inhibition of glycogenolysis in primary rat hepatocytes by 1,4-dideoxy-1,4-imino-D-arabinitol," Biochemical Journal, vol. 342, no. 3, pp. 545-550, 1999.

[6] Y. Zhou, Y. Zhao, K. M. O’Boyle, and P. V. Murphy, "Hybrid angiogenesis inhibitors: synthesis and biological evaluation of bifunctional compounds based on 1-deoxynojirimycin and aryl-1,2,3-triazoles," Bioorganic and Medicinal Chemistry Letters, vol. 18, no. 3, pp. 954-958, 2008. 
[7] H. C. Kolb, M. G. Finn, and K. B. Sharpless, "Click chemistry: diverse chemical function from a few good reactions," Angewandte Chemie International Edition, vol. 40, no. 11, pp. 20042021, 2001.

[8] R. Huisgen, G. Szeimies, and L. Mobius, "1.3-Dipolare Cycloadditionen, XXXII. Kinetik der Additionen organischer Azide an CC-Mehrfachbindungen," Chemische Berichte, vol. 100, no. 8, pp. 2494-2507, 1967.

[9] C. W. Tornoe, C. Christensen, and M. Meldal, "Peptidotriazoles on solid phase: [1,2,3]-triazoles by regiospecific copper(I)-catalyzed 1,3-dipolar cycloadditions of terminal alkynes to azides," The Journal of Organic Chemistry, vol. 67, no. 9, pp. 3057-3064, 2002.

[10] K. V. Gothelf and K. A. Joergensen, "Asymmetric 1,3-dipolar cycloaddition reactions," Chemical Reviews, vol. 98, no. 2, pp. 863-910, 1998.

[11] T. R. Chan, R. Hilgraf, K. B. Sharpless, and V. V. Fokin, "Polytriazoles as copper(I)-stabilizing ligands in catalysis," Organic Letters, vol. 6, no. 17, pp. 2853-2855, 2004.

[12] J. Diot, M. I. Garcoa-Moreno, S. G. Gouin, C. O. Mellet, and K. Kovensky, "Multivalent iminosugars to modulate affinity and selectivity for glycosidases ," Organic and Biomolecular Chemistry, vol. 7, no. 2, pp. 357-363, 2009.

[13] I. Kumar, N. A. Mir, C. V. Rode, and B. P. Wakhloo, "Intramolecular Huisgen [3+2] cycloaddition in water: synthesis of fused pyrrolidine-triazoles," Tetrahedron, vol. 23, no.

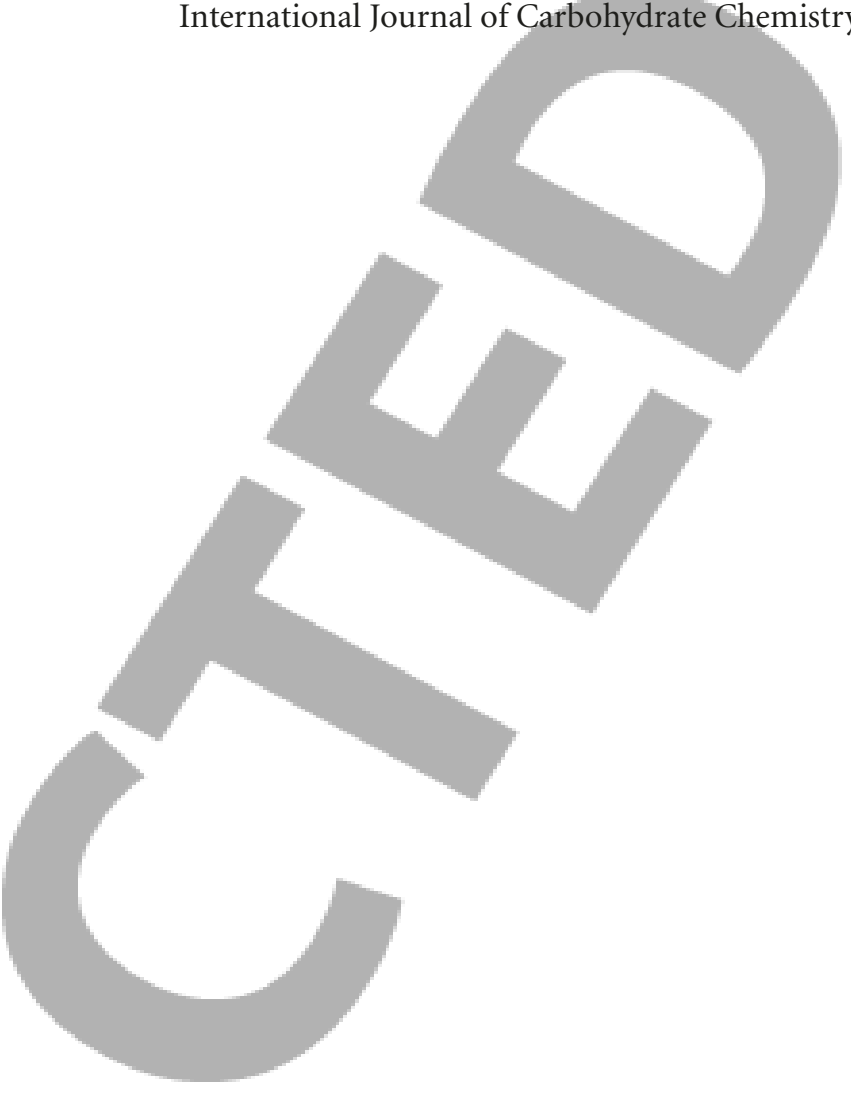
3-4, pp. 225-229, 2012.

[14] V. Haridas, K. Lal, Y. K. Sharma, and S. Upreti, "Design, synthesis, and self-assembling properties of novel triazolophanes," Organic Letters, vol. 10, no. 8, pp. 1645-1647, 2008.

[15] C. Benhaoua, "One-pot synthesis of pyrrolidine-2-ones from erythruronolactone and amine," Organic Chemistry International, vol. 2012, Article ID 482952, 6 pages, 2012.

[16] A. Maisonial, P. Serafin, M. Traïkia et al., "Click chelators for platinum-based anticancer drugs," European Journal of Inorganic Chemistry, vol. 2008, no. 2, pp. 298-305, 2008. 